\title{
Juvenile Hemochromatosis in Iran: A Case Report with 5-Year Follow-up after Treatment
}

\author{
Hossein Nobakht ${ }^{1}$, Sheida Zolfaghari², Mohsen Pourazizi ${ }^{3,4^{*}}$, Mojtaba Malek ${ }^{5}$
}

1. Internal Medicine Department, Semnan University of Medical Sciences, Semnan, Iran

2. Students' Research Committee, Semnan University of Medical Sciences, Semnan, Iran

3. Cancer Research Center, Semnan University of Medical Sciences, Semnan, Iran

4. Department of Ophthalmology, Students' Research Committee, Isfahan University of Medical Sciences, Isfahan, Iran

5. Endocrine Research Center, Institute of Endocrinology and Metabolism, Iran University of Medical Sciences, Tehran, Iran

\footnotetext{
* Corresponding Author: Mohsen Pourazizi, MD Cancer Research Center, Semnan University of Medical Sciences, Semnan, Iran Tel: + 982313354359

Fax: + 982313354359

Email: m.pourazizi@yahoo.com Received: 11 Oct. 2015

Accepted: 08 Jan. 2016
}

\section{ABSTRACT}

Juvenile hemochromatosis is a rare autosomal recessive disorder that typically occurs in the first to third decades of life. Its symptoms are more acute and severe than classic hemochromatosis. We describe a 27 -year-old man who was referred to the gastrointestinal clinic with a probable diagnosis of fatty liver and was finally diagnosed as having juvenile hemochromatosis. A review of the scientific literature reveals that recently only three siblings suffering from the disease have been reported in Iran

\section{KEYWORDS}

Juvenile hemochromatosis, Iron overload, Iran

Please cite this paper as:

Nobakht H, Zolfaghari S, Pourazizi M, Malek M. Juvenile Hemochromatosis in Iran: a Case Report with 5-Year Follow-up after Treatment. Middle East J Dig Dis 2016;8:143146. DOI : $10.15171 /$ mejdd.2016.20

\section{INTRODUCTION}

Hereditary hemochromatosis $(\mathrm{HH})$ refers to a group of hereditary disorders of iron metabolism characterized by iron overload, which leads to excessive accumulation of iron in tissues. It is classified into five major categories based on the age of onset and other factors, such as genetic cause and mode of inheritance. Type 1, or classic hemochromatosis, which is associated with the Human hemochromatosis gene (also known as the HFE gene), is the most common type and is often seen in Caucasians. The other four rare types include type 2 (A and $\mathrm{B}$ ) or juvenile hemochromatosis (JH), type 3 hemochromatosis (transferrin receptor 2 hemochromatosis), type 4 (A and B) hemochromatosis (Ferroportin disease), and a hypoceruloplasminemia. ${ }^{1,2}$

$\mathrm{JH}$ is a rare autosomal recessive disorder, which typically occurs in the first to third decades of life. Its symptoms are more acute and severe than those of classic hemochromatosis and its incidence is equal in men and women., ${ }^{3,4}$

The first case of JH was reported by Bezanc and colleagues in 1932. Their report was about a 20-year-old woman with pigmentary cirrhosis, hepatomegaly, and multiple endocrine insufficiencies who died of cardiac failure. ${ }^{5}$ In 1978 , the disease was recognized as a distinct clinical entity with the description of a 26-year-old woman with heart failure, insulin-dependent diabetes, amenorrhea, and hepatomegaly and a review of previously reported cases of symptomatic idiopathic hemochromatosis. ${ }^{3,6}$

Case reports of $\mathrm{HH}$ have usually been published from western countries. However, in Iran, a few cases of HH type 1 have been reported. ${ }^{78}$ Recently, $\mathrm{JH}$ has been reported in three family members in Iran. ${ }^{9}$

\section{CASE REPORT}

A 27-year-old, married, male student, a known case of secondary hypogonadism and diabetes mellitus from 2 years prior who was receiving tes- 


\begin{tabular}{lcc} 
Table 1: Laboratory data & & \\
\hline Test & Result & Normal Range \\
\hline White Blood Cells & 5000 per cubic millimeter & $(4000-11000)$ per cubic millimeter \\
\hline Hemoglobin & $14.7 \mathrm{~g} / \mathrm{dl}$ & $(11.5-15) \mathrm{g} / \mathrm{dl}$ \\
\hline MCV & $95 \mathrm{fL}$ & $(80-100) \mathrm{fL}$ \\
\hline Platelet & $128000 \mathrm{mcL}$ & $(150000-450000) \mathrm{mcL}$ \\
\hline FBS & $153 \mathrm{mg} / \mathrm{dl}$ & $<126 \mathrm{mg} / \mathrm{dl}$ \\
\hline Triglyceride & $132 \mathrm{mg} / \mathrm{dl}$ & $(40-200) \mathrm{mg} / \mathrm{dl}$ \\
\hline Cholesterol & $155 \mathrm{mg} / \mathrm{dl}$ & $(40-200) \mathrm{mg} / \mathrm{dl}$ \\
\hline Aspartate transaminase (AST) & $70 \mathrm{IU} / \mathrm{L}$ & $<50 \mathrm{IU} / \mathrm{L}$ \\
\hline Alanine transaminase (ALT) & $90 \mathrm{IU} / \mathrm{L}$ & $(20$ to 140$) \mathrm{IU} / \mathrm{L}$ \\
\hline Alkaline phosphatase & $156 \mathrm{IU} / \mathrm{L}$ & $(0.6-6.2) \mu \mathrm{IU} / \mathrm{mL}$ \\
\hline Thyroid-stimulating hormone (TSH) & $1.3 \mu \mathrm{IU} / \mathrm{mL}$ & $(1-6) \mathrm{mIU} / \mathrm{ml}$ \\
\hline Luteinizing hormone (LH) & $2 \mathrm{mIU} / \mathrm{ml}$ & $(1-14) \mathrm{mIU} / \mathrm{ml}$ \\
\hline Follicle-stimulating hormone (FSH) & $0.3 \mathrm{mIU} / \mathrm{ml}$ & $(0.2-1.30) \mathrm{ng} / \mathrm{ml}$ \\
\hline Testosteron & $0.2 \mathrm{ng} / \mathrm{ml}$ & $(6-8) \mathrm{g} / \mathrm{dl}$ \\
\hline Total protein & $7.2 \mathrm{~g} / \mathrm{dL}$ & $(3.5 \mathrm{to} 5) \mathrm{g} / \mathrm{dL}$ \\
\hline Albumin & $4.6 \mathrm{~g} / \mathrm{dL}$ & - \\
\hline HBs antigen & Negative & - \\
\hline Anti HCV & Negative & - \\
\hline ANA & Negative & $(35-180) \mu \mathrm{g} / \mathrm{dL}$ \\
\hline Serum Iron & $259 \mu \mathrm{d} / \mathrm{dL}$ & $(230-450) \mu \mathrm{g} / \mathrm{dL}$ \\
\hline Total iron binding capacity (TIBC) & $360 \mu \mathrm{g} / \mathrm{dL}$ & - \\
\hline Transferrin saturation & $72 \%$ & $\mathrm{mg} / \mathrm{mL}$ \\
\hline Serum Ferritin & $2200 \mathrm{ng} / \mathrm{mL}$ & \\
\hline Serum protein electrophoresis & Normal & \\
\hline & & \\
\hline
\end{tabular}

tosterone and oral medication for diabetes control, was referred to gastrointestinal clinic with the probable diagnosis of fatty liver, due to impaired liver function tests. He did not complain of arthralgia or dyspnea. There was no family history of diabetes mellitus or thyroid dysfunction. He did not smoke or use alcohol. A pigmented tan skin and hepatosplenomegaly were the positive findings in his physical examination. Various tests were performed to investigate the possibility of iron overload and chronic liver diseases (Table 1).

By sonography, his liver was reported larger than normal $(165 \mathrm{~cm})$ with heterogeneous echo. In his esophagogastroduodenoscopy, there was no evidence of esophageal varices. His echocardiography was normal. In non-contrast abdominal computed tomography, increased density of liver compared with spleen was reported (figure 1). A T2-weighted, gradient echo axial image of the patient demonstrated diffuse abnormal low signal intensity of the liver. The pancreas and spleen appeared normal (figure 2). Finally, a liver biopsy was performed, which showed extensive liver fibrosis and nodule formation. Iron staining (pearl's stain) showed diffuse extensive iron deposition in all hepatocytes and Kupffer cells. The diagnosis based on the biopsy was extensive cirrhosis (6/6) with severe iron overload (4/4).

According to the clinical presentations, age less than 40 years, high ferritin levels $(2200 \mathrm{ng} / \mathrm{mL})$, transferrin saturation $(72 \%)$, and MRI findings, iron overload was considered in this patient, and $\mathrm{JH}$ was diagnosed.

Follow-up: The patient was treated with phlebotomy every two weeks for 18 months, but there was no significant drop in iron saturation despite a drop in hemoglobin to $12 \mathrm{gr} / \mathrm{dL}$. An iron chilator, deferasirox (500 mg twice daily), was added to the treatment. After 18 months of treatment with deferasirox, his iron saturation decreased to $20 \%$, ferritin level decreased to $20 \mathrm{ng} / \mathrm{mL}$, and liver function test normalized. Deferasirox was discontinued, and the phlebotomy interval was increased based on his 


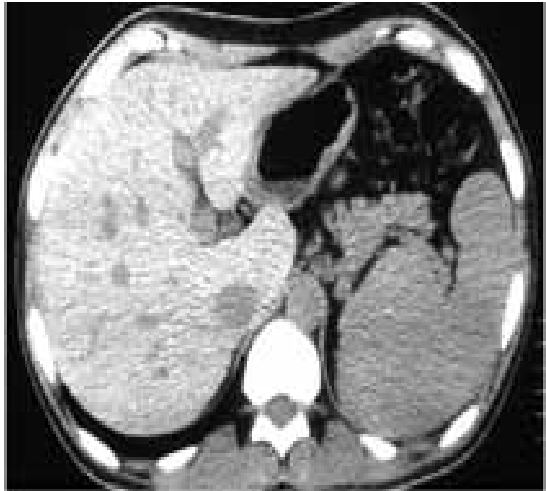

Fig.1: Non-contrast abdominal tomogram showing increased density of liver

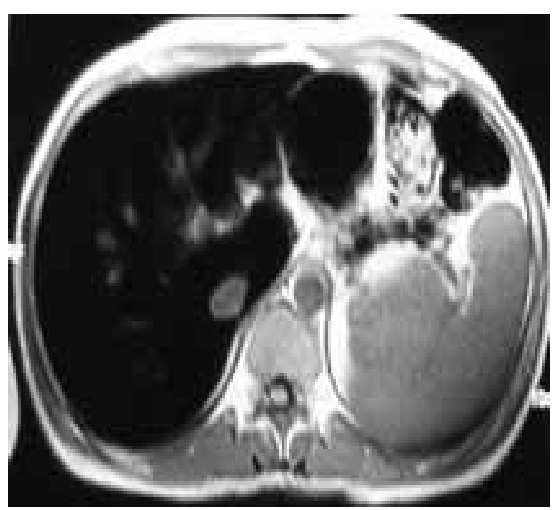

Fig.2: T2-weighted MRI shows diffuse abnormal low signal intensity of the liver

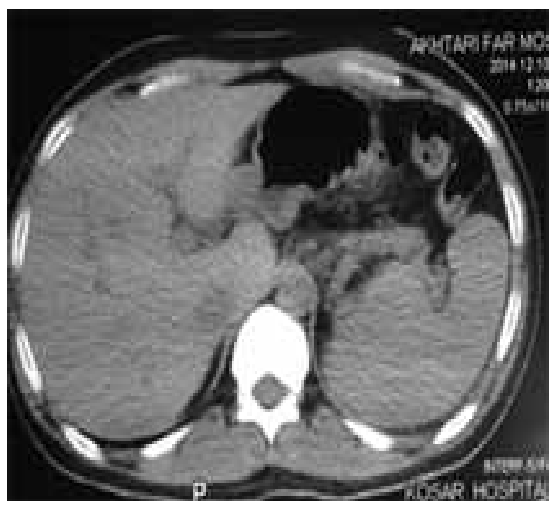

Fig.3: Non-contrast abdominal computed tomography after five years of treatment shows significant decrease in liver density

hemoglobin level.

After 5 years of treatment, his insulin requirement decreased by $50 \%$, but sexual dysfunction persists. A non-contrast computed tomography of liver showed significant decrease in liver density (figure 3 ).

\section{DISCUSSION}

$\mathrm{HH}$ is rarely reported in Iran. The first report of $\mathrm{HH}$ in Iran was published by Nobakht and colleagues in $2006,{ }^{7}$ and few cases of this disease have been reported after that. ${ }^{8}$ Review of the scientific literature reveals only one recent (2014) report of JH in Iran by Malekzadeh and co-workers. ${ }^{9}$

$\mathrm{JH}$ is a rare autosomal recessive disease. Its physiopathology is associated with impaired regulation of hepcidin hormone, which is produced by hepatocytes. Hepcidin plays an important role in iron homeostasis by regulating its absorption and release in enterocytes and macrophages. ${ }^{4,10}$

Prevalence of $\mathrm{HH}$ varies in different ethnic groups. It is more prevalent in northern Europe, where almost $10 \%$ of its population are heterozygous carriers and approximately $0.5 \%$ are homozygous. ${ }^{2,11}$ More than $80 \%$ of cases have HH type 1 (associated with the gene HFE), and $20 \%$ have other rare types of this disease. ${ }^{4}$

JH should be suspected in any child, adolescent, or young adult with findings of iron overload. The suspicious findings are hypogonadotropic hypogonadism, hepatomegaly, cirrhosis, liver cancer, diabetes mellitus, cardiomyopathy, arrhythmia, arthritis, and progressive skin pigmentation. ${ }^{2,12,13}$

Initial manifestation in our case was secondary hypogonadism and diabetes mellitus. The first presentation of the disease has not been considered conclusive, but the signs and symptoms of hypogonadism, cardiac involvement, and an impaired liver function test are the most common findings reported in this disease..$^{4,13}$

Although diabetes mellitus is common in patients with classic $\mathrm{HH}$, its prevalence is not well defined in patients with $\mathrm{JH}$. However, in our case, the chief complaints that led the patient to refer to a physician were the symptoms of polyuria and polydipsia. De Gobbi and colleagues have also pointed to the presence of diabetes mellitus symptoms in their report of several patients with $\mathrm{JH} .{ }^{13}$

Presenting symptoms in the first or second decade may be less specific. They include lack of appetite, fatigue, amenorrhea, or arthralgia. If it is not diagnosed in early stages or remains untreated, it can lead to death, mainly due to heart failure..$^{13,14}$

Laboratory data for JH is limited because documented cases of $\mathrm{JH}$ are rare. However, tests for serum ferritin 
concentration and transferrin-iron saturation should be performed. ${ }^{2}$ MRI is useful as a non-invasive method to determine the iron overload in the liver. ${ }^{15}$ Also in a liver biopsy, a hepatic iron index greater than 1.9 is suggestive of iron overload. ${ }^{2,14}$ Two gene mutations associated with JH are HJV and Hepcidin antimicrobial peptide (HAMP) genes, which encode hemojuvelin and hepcidin, respectively. HJV mutation is seen in more than $90 \%$ of patients, and HAMP is based on the clinical presentations, abnormal laboratory data, and proper response to treatment. Genetic tests were not performed due to their lack of availability.

Despite the more severe iron overload seen in $\mathrm{JH}$ (as compared with classic $\mathrm{HH}$ ), hepatocellular cancer has not been reported in $\mathrm{JH}$. A possible explanation is that untreated individuals with $\mathrm{JH}$ die prematurely as a result of cardiac complications. ${ }^{2,6}$ Effective treatment can significantly restrict the progression of the symptoms, complications, and mortality if the disease is diagnosed in early stages.

\section{ACKNOWLEDGEMENT}

This study was supported by Internal Medicine Department, Semnan University of Medical Sciences, Semnan, Iran.

\section{CONFLICT OF INTEREST}

The authors declare no conflict of interest related to this work.

\section{REFERENCES}

1. Brissot $\mathrm{P}$, Troadec $\mathrm{MB}$, Bardou-Jacquet $\mathrm{E}$, Lan CL, Jouanolle AM, Deugnier Y, et al. Current approach to hemochromatosis. Blood Rev 2008;22:195-210. doi:10.1016/j. blre.2008.03.001

2. Crownover BK, Covey CJ. Hereditary hemochromatosis. Am Fam Physician 2013;87:183-90.

3. Lamon JM, Marynick SP, Roseblatt R, Donnelly S. Idiopathic hemochromatosis in a young female. A case study and review of the syndrome in young people. Gastroenterology 1979;76:178-83.

4. Santos PC, Dinardo CL, Cançado RD, Schettert IT, Krieger JE, Pereira AC. Non-HFE hemochromatosis. Rev Bras Hematol Hemoter 2012;34:311-6. doi: 10.5581/1516-8484. 20120079.

5. Bezançon F, De Gennes L, Delarue J, Oumensky V. Cirrhose pigmentaire avec infantilisme, insuffisance cardiaque et aplasies endocriniennes multiples. Bull Mém Soc
Méd Hop Paris 1932;48:967-74.

6. Camaschella C, Roetto A, De Gobbi M, editors. Juvenile hemochromatosis. Seminars in hematology; 2002: Elsevier.

7. Nobakht H, Merat S, Malekzadeh R. Hereditary hemochromatosis: a rare disease in Iran. Arch Iran Med 2006;9:78-80.

8. Zamani F, Bagheri Z, Bayat M, Fereshtehnejad SM, Basi A, Najmabadi $\mathrm{H}$, et al. Iranian hereditary hemochromatosis patients: Baseline characteristics, laboratory data and gene mutations. Inter Med J Exper Clin Res 2012;18:CR622.

9. Malekzadeh M, Radmard AR, Nouroozi AR, Akbari MR, Amini M, Navabakhsh B,et al. Juvenile Hemochromatosis, Genetic Study and Long-term Follow up after Therapy. Middle East J Dig Dis 2014;6:87-92.

10. Fleming MD. The regulation of hepcidin and its effects on systemic and cellular iron metabolism. Hematology Am Soc Hematol Educ Program 2008:151-8. doi: 10.1182/ asheducation-2008.1.151.

11. Edwards CQ, Griffen LM, Goldgar D, Drummond C, Skolnick MH, Kushner JP. Prevalence of hemochromatosis among 11,065 presumably healthy blood donors. $N$ Engl J Med 1988;318:1355-62.

12. Goldberg YP. Juvenile Hereditary Hemochromatosis. In: Pagon RA, Adam MP, Ardinger HH, Wallace SE, Amemiya A, Bean LJH, et al., editors. Gene Reviews (R). Seattle (WA) 1993.

13. De Gobbi M, Roetto A, Piperno A, Mariani R, Alberti F, Papanikolaou G, et al. Natural history of juvenile haemochromatosis. Br J Haematol 2002;117:973-9. doi: 10. 1046/j.1365-2141.2002.03509.x

14. McDonald CJ, Wallace DF, Crawford DH, Subramaniam VN. Iron storage disease in Asia-Pacific populations: The importance of non-HFE mutations. $J$ Gastroenterol Hepatol 2013;28:1087-94. doi: 10.1111/jgh.12222.

15. Gandon Y, Olivie D, Guyader D, Aube C, Oberti F, Sebille $\mathrm{V}$, et al. Non-invasive assessment of hepatic iron stores by MRI. Lancet 2004;363:357-62. doi: 10.1016/S01406736(04)15436-6. 